\title{
DIE NA-OORLOGSE KERKREGTELIKE ONTWIKKELING IN DIE GKSA
}

\author{
Prof. B. Spoelstra
}

\section{AFHANKLIK OF SELFSTANDIG ?}

Prof. G. P. L. v. d. Linde het in 'n voordrag voor die Aktualiteitskursus gedurende Julie 1978 te Potchefstroom die stelling gemaak dat die kerkregtelike ontwikkeling binne GKSA-kringe in die naoorlogse periode feitlik heeltemal van sy Europese en Nederlandse voedingsbodem losgemaak is en selfstandig geword het. (In die Skriflig, nr. 48, Desember 1978). Hierdie stelling beskryf die algemene tendens van die kerkregtclike ontwikkeling van dic GKSA na 1945. Tog is daar ook 'n ander aspek wat waarskynlik nog nie na behore nagevors is nie en ook nie in hierdie studic aan die orde kan kom nie, naamlik die vraag in hoeverre kerkregtelike patrone en praktyke van ander Afrikaanse Kerke, van na-oorlogse ekumeniese bewegings ens., tendense uit Nederland ens. denke beinvloed en pleidooie oor kerklike opset en inrigting ontlok het wat 'n neerslag in kerkregtelike ontwikkeling gehad het.

\section{BEGRIPPE KERKREGTELIK EN ONTWIKKELING}

Die begrip „kerkregtelike ontwikkeling” moet nader bepaal word. Kerkregtelik: Kerkreg moet liefs as tetiese en ekklesiologiese dissipline van kerkregering, as praktiese of diakonologiese dissipline (kubernetiek, Kuyper), onderskei word. Onder kerkregtelik moet konstituerende of konstitutiewe beginsels verstaan word wat regstreeks aan die Skrif as principium theologiae ontleen is. Die behoud van die beginsels (o.a. sy ontstaan vanuit die verkiesing) maak die kerk 'n unieke samelewingsverband wie se bestaan en vorm deur die wil van God bepaal word. Daardeur is die Kerkreg eintlik normatiewe wetenskap vir die kerkkonstituering, kerkordelike ontwikkeling en kerkregering.

Onder kerkregering moet die bepaalde „konstitusionele” instelling, orde of wet van die bepaalde kerk of kerkfamilie verstaan word wat die identiteit bepaal soos dit prakties, sigbaar en kenbaar as ' $n$ bepaalde instelling optree. So kom by die kerkregering veral twee aspekte na vore: eerstens die basiese strukturerende en konstituerende kerkwet of kerkorde en tweedens handelinge, besluite, bepalinge en soms selfs opdragte aan persone t.o.v. ligpame en instansies, waarin die betrokke kerkgemeenskap homself laat geld. Die opvatting oor kerkreg aan die een kant en kerkinrigting en kerkregering aan die ander kant, verskil ingrypend na gelang die bron van gesag verskil. Wanneer Kerkreg hom besig hou met die Skrif (soos Calvyn in sy Institusie), is God die outeur van kerkreg en voer Hy gesag oor wat die reg in die kerk is.

In die kerkregering tree mense in sekere ,ampte" op en hulle kom in vergaderings saam en kan as sodanig outeur(s) van die reg 
word. Sodoende kan (by wyse van woordspeling) onder die naam „kerkreg” juis ,onreg" bedryf word. Ek neem aan dat met ,kerkregtelike" vir hierdie referaat veral gevra word na wat in die kerkregering soos dit deur mense uitgevoer is, gebeur het m.b.t. die instituut, konstitutiewe en strukturele aspekte. Die begrip „ontwikkeling" loop gevaar om weer eensydig 'n ewolusionistieseoptimistiese en selfs subjektiewe opvatting na vore te bring asof elke latere besluit beter is omdat dit jonger is. Hierdie gevaar is glad nie denkbeeldig nie. Die feit dat kerklike persone in stryd met kerkreg in die Skrif kan handel en so onreg in kerklike handelinge kan vaslê, bring mee dat gewaande ,ontwikkeling" agteruitgang mag wees vir iemand wat Skriftuurlike norme aanlê terwyl 'n ander uit pragmaties-horisontale hoek dit hoog mag aanslaan.

\section{DIE BRUG TUSSEN VOOR EN NA-OORLOGSE KERKBEGRIP} EN KERKREGERING

In die voor-oorlogse periode kom die „kerkbegrip” aan die een kant meer "genootskaplik", gesentraliseerd voor. Daar is 'n besef van „ons kerk”, die „Gereformeerde Kerk”. Die begrip is egter meer ' $n$ idee, ' $n$ aanvoeling van geestelike eenheid en word nie met "sinode" vereenselwig nie. Die sinode kan 'n geleentheid wees waar die ,hele kerk" oor 'n aangeleentheid sy stem laat hoor maar die sinode was nie kerk nie. Aan die ander kant het die selfstandigheid, onaantasbaarheid, verantwoordelikheid en vryheid van die plaaslike kerke t.o.v. sinodes voor die oorlog baie duidelik en sterk na vore gekom. Plaaslike kerke wou nie in sake deur klassisse en sinodes voorgeskryf word nie. In die patriargale en ,unie"-bedeling op sosiale en politieke gebied het daar telkens versoeke gekom dat sinodes ter wille van kerklike „eenvormigheid" moet voorskryf t.o.v. wat plaaslik ter sake was, soos wanneer by 'n erediens gekollekteer word, die sing van Skrifberyminge, 'n kerklike kleed, dienstyd van kerkdienaars, traktement van predikante, ens. Dit is telkens aan kerkrade oorgelaat (art. $30 \mathrm{KO}$ ) om daaroor te besluit. Voor 1940 is kerkregtelik 'n eenheidsbesef soos by 'n groot intieme familie aanwesig en 'n behoefte om dieselfde beginsels in onderwys, politiek, kultuur en praktyk na te leef, maar die uitvoering het met 'n lewende plurale praktyk rekening gehou. Dit is 'n feit dat sentralisasie (wat administratief "makliker" en ,beter" werk en gewoonlik pragmaties ideaal word) per definisie noodwendig plaaslike vryhede en verantwoordelikhede wegneem en na die sentrale pool delegeer.

In die periode na 1945 kan die „kerkbegrip" in talle sinoderapporte teologies gelees word. Daarin word die plaaslike kerk toenemend as komplete en volkome openbaring van die Liggaam van Christus gestel (vgl. Acta 1955, p. 70 v.; 1964, p. 155 v.; 1967, p. $359-411 ; 1970$, p. 58 v.; ens.). Die praktiese kerkregtelike ontwikkeling gaan egter gelyktydig in stryd daarmee na 1940 toenemend in die rigting van sentralisasie. Die selfstandigheid, verantwoordelikheid en selfs vryheid van die plaaslike kerke is toenemend ingekort met 'n beroep op „die kerkverband”. Die plurale gemeenskap 
van plaaslike kerke, saamgebind deur 'n hegte geloofsband (vgl. familieband) waarkragtens ,saam" met ander ,kerke" en met "direkte afvaardiging van elke kerkraad" sinode gehou is - het al meer die rigting van 'n organisatoriese eenheid opgegaan. Die "sinode" moes vir die kerke voorsê. Die ,sinode" en ,sinodebesluite" is toenemend as riglyn vir plaaslike handelinge aangevra en aangevoer. „Klassis-" en ,sinodebesluite” is aangedien asof die klassis of sinode 'n ander gesag (,kerkverband") is wat aan die kerkraad voorskrywe. 'n Voorbeeld: Sinodes wou nooit salarisskale adviseer nie. $\mathrm{Na}$ die oorlog het talle klassikale ,riglyne” die lig gesien wat met visitasie "namens die klassis" aan kerkrade opgelê is. Visitasie het die vorm van klassis-inspeksie i.p.v. ter plaatse worsteling met probleme aangeneem. Met sending, sustentasie, diakonale sake, kollektes vir behoeftige gemeentes, ens. is toenemend onder 'n sinodale sambreel gewerk. Die voorkoms van die praktyk bring meer ,eenvormigheid" mee, maar tegelykertyd is die kerke en gelowiges al minder betrokke, voel hullesclf minder verantwoordelik en stel al minder belang in die sogenaamde „kerklike bedrywighede" wat op sinodes ter sprake is.

Die belewing van kerklike eenheid en gemeenskap of „kerklike familieskap" het in die na-oorlogse periode verdwyn juis toe 'n meer formele, institusionele en gesentraliseerde organisasie ontplooi het. 'n Meer gemoedelike, landelik-gefundeerde lewensgemeenskap waarin die kerk plaaslik en ,kerke" in kerkverband leefwyse en gemeenskap was, het in 'n meer formele organisasie ('n instituut?) oorgegaan.

In baie opsigte het die horison vereng. In plaas van plurale kerke wat worstel met die lewensstroom waarin die gelowiges swem, het die plaaslike kerke opgegaan in agenda wat grootliks met die institusionele bestaan van die kerk as sodanig verband hou'.

ONAFHANKLIKE KOERSWYSIGING T.O.V. DIE GEREF KERKEN VAN NEDERLAND

Die GKSA het t.o.v. die GKN (meer as wat by die GKN t.o.v. GKSA die geval was) ' $n$ intieme en sensitiewe identifikasie gekoester. Laasgenoemde het gewoonlik vir die GKSA as model en teologiese arsenaal gedien. Dit kan nie gesê word dat die GKSA van die GKN afhanklik was nie. Hoewel die GKSA sedert 1959 'n eie Afrikaanse karakter dra en daarvolgens ontwikkel, het teologiese werke en canonici uit die GKN met hulle onderneminge soos die VU, publikasies Calvinistiese bewegings, verenigings en skoolstryd vir die GKSA tot voorbeeld gedien. Die GKN wysig in 1905 die Kerkorde en die GKSA volg op dieselfde spoor in 1916. Die GKN het 'n Schildersaak in 1944. Die GKSA het 'n De Wetsaak in 1946 (uiteraard met ander materie). Die GKSA het reeds in 1924 die ideaal van een ekumeniese Gereformeerde Sinode aan die GKN en CRC van die VSA deurgegee. Dit lyk asof daar werklik 'n kerkregtelike eenheid binne die Geref. Ekumeniese Sinode in 1946 te Grand Rapids tot stand gaan kom. Dit het egter nie werklikheid geword nie omdat juis die GKN nie so 'n ekumeniese sinode wou gehad het nie. Nietemin 
het die Sinode van 1949 in SA getrag om die verskillende NG Kerke, die NHK van A en talle Engelse Kerke, in die veel losser ekumeniese verband wat as die GES bekend geraak het, te betrek. Dit verraai 'n basiese kerkregtelike openheid met ander kerkgroeperinge wanneer eenheid in belydenis aangevoel en onderken was.

Binne die GKN het nuwe na-oorlogse tendense na vore getree. Kerkregtelik gesproke het M. Bouwman se proefskrif, Voetius over het gezag der Synoden (1937) in Nederland 'n groot koerswysiging veroorsaak, mede a.g.v. die tragiese kerkskeuring in 1944. Bouwman het genootskapsreg van die $18 \mathrm{e}$ eeu op Voetius geprojekteer en hom herinterpreteer en gelees met 'n bril wat plaaslike kerk en sinode bipolêr onderskei asof die plaaslike kerk deur 'n kerkraad en die „kerkverband" deur meerdere vergaderings regeer word. A.g.v. die skeuring in 1944 en die reaksie onder hulle jeug, het die na-oorlogse ekumeniese beweging die GKN ook spoedig op die WRK gerig. Die proses is versnel omdat die dekolonialisasie in Indonesië die GKN op sendingterrein met leë hande laat staan het. In plek van koloniale betrokkenheid het die GKN na internasionale betrokkenheid gesoek. Die nuwe benadering het daartoe gelei dat die GKN hulle kerkordelike basis, naamlik die Dordtse Kerkorde, vanaf 1944 wou ,hersien". In die Schildersaak was die tugreg van die sinode in gedrang. Die GKN het die eerste „voorlopige” resultaat aan die GKSA vir kommentaar gestuur.

Die GKSA het sy eenheid met die GKN steeds in Belydenis, Liturgie en Kerkregering gesoek. Die Sinode van die GKSA van 1952 is voor die voldonge feit geplaas dat die GKN een van die grondpilare van die eenheid ,hersien" en slegs kommentaar gevra het. Op geen GES is bv. uitgemaak dat die DKO nie meer deug nie. Die Sinode van 1952 het geen behoefte aan 'n ,deurtastende revisie" gevoel nie, maar het tog die GKN probeer tegemoet kom. Die Sinode van 1955 het verneem dat die GKN talle van die artikels van die DKO as verouder beskou of wou aanvul, nuwe sake wou reël en die kerkregering wou moderniseer (Hand. bls. $173 \mathrm{v}$ ). Die Sinode van 1955 het aan deputate opgedra om die DKO soos in gebruik by die GKSA in hierdie lig te bekyk en sonder „,nodelose afwyking van die DKO" 'n hersiene KO by die volgende Sinode voor te lê. Die resultaat het in baie opsigte die hersiening in Nederland op die voet gevolg en die bipolêre opvatting van kerkraad en sinode, reglementering van die plaaslike kerke deur sinodes, elemente van klerikalisme (waar die ampsdraer die kerk verteenwoordig) nagevolg.

Die Sinode van 1958 het hierdie konsep na die kerke (gemeentes) vir kommentaar verwys (Acta 1958, p. 108). Moontlik het die groot entoesiasme met die eeufees in 1959 van die eerste kerk te Rustenburg die wye belangstelling en aandag vir die Kerkordehersiening gestimuleer. Die deputate het baie kommentaar ontvang maar met die basiese bipolêre opvatting volhard. Daarvolgens vorm klassisse en sinodes as meerdere vergaderings een bepaalde vorm van kerkstruktuur teenoor die kerkraad en plaaslike kerk. Die Sinode het hierdie basiese wysiging en voorgestelde konsep nie aanvaar nie. Deputate is nou uitdruklik aan die bestaande kerk- 
ordelike basis (die Dordtse Kerkorde) gebind. Die bestaande Kerkorde moes sinvol hersien word (Acta 1961, p. 347). Hierdie besluit verteenwoordig die moment waarop die weë van die GKSA en die GKN vorentoe noodwendig uitmekaar moes loop. Met twee verskillende kerkregeringstelsels het die korrespondensie van 'n eeu in die gedrang gekom.

Die Sinode van 1964 het talle besluite geneem waarin doelbewus tipiese gereformeerde kerkregeringsbeginsels uit die 16de eeu herwaardeer en toegepas is. Die Sinode het ook op enkele artikels na 'n hersiene Kerkorde goedgekeur. Die basiese bepalinge van die Dordtse Kerkorde en beginsels van Calvyn se Institusie (Boek IV) en die Ned. Geloofsbelydenis (art. 27-32) is behou. Daarvolgens rus die universele kerk of liggaam van Christus in God se ewige verkiesing. Hierdie een kerk word sigbaar op elke bepaalde plek waar Woord en Sakramente bedien word en die gemeente in goeie orde met dissipline wat met die Woord ooreenkom deur ouderlinge geregeer word. Met die oog op die eenheid in geloof (Belydenis) en handhawing van die gehoorsaamheid aan Christus, die enigste Hoof van die kerk (tug), moet die kerke mekaar in die kerkregering bystaan. So kom die kerke in gesette tye binne bepaalde streke as kerke in ad hoc sinodes (klassisse, ens.) saam. Soos die Independente erken die Kerkorde die primêre konstitutiewe betekenis van die Woordbediening, kerklike dienste en kompleetheid van die kerk op 'n bepaalde plek. Anders as die kollegialiste word sinodes nie as eenheid van gemeentes en so as algemene of hele kerk beskou nie. Die ,kerk" is nie 'n eenheid van gemeentes nie. Daarom het die klassis 'n baie groter betekenis as sinodes in die lewe van die kerke. Die sinodes behoort hulle te bepaal by gemeenskaplike sake soos Belydenis, Kerkorde ens., waarin essensiële akkoord van gemeenskap tussen die selfstandige plurale plaaslike kerke uitgedruk is. Die eenheid van die kerk is dus wesenlik 'n eenheid in Christus, 'n geloofseenheid, wat die konfederatiewe kerkregering enersyds moontlik en andersyds noodsaaklik maak, juis om die eenheid te beskerm. Demonstrasie van eenheid van die kerk ter wille van eenheid (in organisasie) soos in die 20ste eeu met sy ekumene bepleit, het in die Kerkorde van 1571 tot 1619 geen rol gespeel nie.

Hierdie ietwat uitvoerige aanduiding van die beginsel in die $\mathrm{DKO}^{2}$ is om twee redes belangrik. Eerstens bied dit 'n norm waarmee kerkregtelike geskiedenis na 1945 t.o.v. GKSA waardeer kan word en bepaal kan word of sinodokratisering toegeneem het. Tweedens beklemtoon die prinsipiële basis die identiteit van die GKSA t.o.v. die NGKSA en NHK. Dit verklaar waarom die Interkerklike gesprek $^{3}$ met die verskille in kerkbegrip gekonfronteer word. In die vraag na "kerklike eenheid" tussen die drie Afrikaanse kerkgemeenskappe sal hierdie identiteit onder oë gesien moet word. Die Gereformeerde beginsel sal of die basis vir kerkregering moet vorm, of daarvan sal soos by die GKN doelbewus afstand gedoen moet word. Die kerkregtelike opvattings word grootliks bepaal deur die kerkbegrip.

Nog voordat die GKN by die WRK aangesluit en die PCR vir 
sy rekening geneem het, het die Sinode van 1967 die kerklike eenwees (korrespondensie) tussen die GKSA en die GKN bevraagteken. Deputate ontvang derhalwe opdrag om 'n deeglike studie van die Hersiene Kerkorde van die GKN te maak (GKSA Acta 1967, p. 429 e.v.). Die Sinode van 1970 word ingelig dat die figerende kerkorde van die GKN t.o.v. kerkbegrip, ampsbegrip, gesagsbegrip en ordebegrip die kerkregtelike basis van die Dordtse KO verlaat het (Acta 1970, p. 99). Weldra verneem latere Sinodes dat predikante en professore binne die GKN van die Belydenis en Skrifgesag en die Versoening afwyk sonder dat die eenheid in geloof gehandhaaf word. Die eenheid in geloof was dus de facto tussen die GKSA en GKN verbreek sodat ' $n$ de jure breuk noodwendig moes volg indien geloofseenheid as voorwaarde vir Kerklike eenheid (korrespondensie) gestel word. Slegs wanneer organisatoriese eenheid meer as die geestelike eenheid weeg, sou die historiese betrekkinge gehandhaaf kon bly. Hoe pynlik ookal, moes die Sinode van 1976 verklaar dat die GKSA met die GKN nie meer een in leer, diens en tug (d.w.s. kerkregering) is nie (Sinode 1976, p. 302).

Die feit dat die GKSA kerkregtelik op die historiese bane van die DKO bly beweeg het, het derhalwe gelei tot 'n institusionele (korrespondensie in enger sin) breuk met die GKN wat in die na-oorlogse jare gepaard met pragmatisme, ekumenisme en afwyking van die Gereformeerde leer, ook 'n nuwe kerkregtelike bedeling ingegaan het.

\section{DIE GKSA IN DIE INTERKERKLIKE SITUASIE}

\section{Die Interkerklike Kommissie}

Dit skyn asof ds. D. F. B. de Beer van die NGKSA se stryd teen „sosiale euwels" ook die ander kerke, aanvanklik dalk as meelopers, by 'n menigte sake betrek het: dobbelary, sabbatsontheiliging, ontstigtelike lektuur, egskeiding, owerspel, opening van skole op Maandae, Gemengde Huwelike (wat slegs in Transvaal verbied was), laster, ongewenste kleredrag, skoonheidswedstryde, lykverbranding, nagklubs, verkoop van petrol op Sondae, Sondagarbeid by die SAS, moedertaal op skole, die Instituut vir CNO van die FAK, onderwys vir volwassenes, Kommunisme (waaroor saam 'n kongres 1946 gehou is), immigrasie ens. Talle Geref. Kerkrade het skynbaar nie veel erg gehad aan die optredes van die drie kerke deur die Interkerklike Kommissie nie (Sinode 1949, p. 197).

Die IKK was geneig om elke keer bloot kerkisties oor oorgaan van lidmate van een kerk na ' $n$ ander te handel. Die moontlikheid van 'n Raad van Kerke tussen ,Susterkerke" met die oog op gemeenskaplike en volksbelange in die IKK is deur die Sinodes van 1952 (Hand. p. 188) en 1955 (Hand. p. 269) oorweeg. Die GKSA het egter in 1955 vir so 'n strukturele kerklike band teruggehuiwer en wou die IKK laat bly soos dit was (p. 271).

Ondertussen het uit die ekumeniese bewegings soos die WRK en die GES toenemend 'n nuwe probleem na vore gekom wat as die probleem oor die eenheid van die kerk geformuleer is. Hierdie probleemstelling is eie aan die eeu van ekumenisme. Dit gaan om 
eenheid in organisasie, terwyl die begrip kerk slegs 'n adjektief vorm. Die kerk, die liggaam van Christus daarenteë is per definisie een, d.w.s. kerk is eenheid. Hierdie universele eenheid kom egter in plurale kerke (gemeentes) in baie lande, volke, tale na vore. Veelheid op aarde is onmiskenbaar die wyse waarop die een kerk van Christus empiries geken word. Wanneer bepaalde kerke (gemeentes) met mekaar 'n kerkordelike ooreenkoms aangaan om in sinodes mekaar met die kerkregering te ondersteun geskied dit kragtens ' $n$ eenheid in Christus. Die eenheid is ecnheid en een van die "gawes" van God aan sy kerk is die "regering". Ek meen dat enersyds die Roomse kerkbegrip wat die wese van die kerk in sy regeerders soek en andersyds van die 18de eeuse Liberalisme wat die "kongres" verteenwoordigend van die genootskap maak, veroorsaak het dat die "eenheid van die kerk" met eenheid in kerkregeringsorganisasie vereenselwig is.

Die GKSA het die probleem van eenheid as organisatoriese eenheid afhanklik gemaak van die vraag na eenheid in belydenis en die ander twee Afrikaanse Kerkgemeenskappe opgeroep tot 'n „kerklike" gesprek oor die opvattings wat die kerke uitmekaar hou. Die GKSA het voorop die kerkbegrip op die agenda geplaas. Die gesprek het jare gesloer en eers teen 1977 min of meer op dreef gekom. Hierdie gesprek is eerder 'n „teologiese" as 'n „kerklike" gesprek. Nietemin bring dit interessante kontak, gedagtewisseling en geleenthede vir samewerking mee.

\section{Die Bestryding van Sosiale Euwels}

Die vraag of die GKSA d.m.v. 'n paar deputate saam met amptenare uit ander kerkgroepe moet meedoen aan die bestryding van sosiale cuwels, is deur die Sinode van 1967 negatief beantwoord. Op kerkregtelike gronde is aangevoer dat ' $n$ kerkvergadering sy taak nie deur 'n groep persone kan laat doen nie; die geestelike bestuurswyse van die kerk, roeping van die ampte en plek van die kerklike tug vereis kerklike optrede en nie 'n paar deputate nie. Die deputate kan ligtelik indring op die terrein van die owerheid en van onskriftuurlike metodes gebruik makk (Acta 1967, p. 90 v).

Hierdie besluit is in meer as een opsig belangrik. Dit beklemtoon op kerkregtelike gebied die plurale beginsel. Tog loop die besluit ook weer gevaar dat die kerklike getuienis nie deur die Christene buite hulle plaaslike kerk uitgedra word nie. So word die kerk in 'n institusionele kompartement (vgl. Kuyper se soewereine kringe) teruggedruk en kom van die heerskappy van Christus oor die hele lewe niks tereg nie. Hierdie opset is net so min as die delegering van die getuienisroeping op 'n paar siondale amptenare wat as ",kerk" praat tot eer van God. Binne die GKSA het die opvatting vanuit die GKN posgevat dat Gereformeerdes juis in ander verenigings en organisasies georganiseer moet word vir hulle maatskaplike roeping. Kerkregtelik beskou, het die beginsel waarvolgens die gelowiges in die plaaslike kerk hulle maatskaplike, politieke, ekonomiese roeping na buite moet uitlewe, nog nie tot sy reg gekom het. Die teorie van komplete selfstandige kerke word nie in die praktyk, behalwe t.o.v. eng plaaslike kerkbelange, weerspieël nie. 


\section{Die Gereformeerde Ekumeniese Sinode}

Eienaardig genoeg het die GKSA reeds in die vorige eeu uiting gegee aan die ideaal van 'n Gereformeerde Ekumeniese Sinode. Sinodes in 1918, 1924 en 1927 het daadwerklik met die GKN en CRC in die VSA geskakel. Die elionomiese depressie en Tweede Wêreldoorlog het die saak vertraag totdat te Grand Rapids in 1946 die eerste byeenkoms van die drie kerke plaasgevind het. Die drie kerke het met mekaar in enger korrespondensie gestaan, d.w.s. hulle het dieselfde leer, diens en kerkregering gehad, hoewel hulle territoriaal, nasionaal en sinodaal afsonderlik geleef het. Idealiste uit die GKSA wou 'n ware ekumeniese sinode in lyn met art. 36 DKO daarstel wat oor leerstellige en kerkregtelike vraagstukke, soos bv. die hersiening van art. $36 \mathrm{NGb}$ of die Kerkorde, bindende besluite sou neem. Oudl. A. K. Bot het in 1952 'n meer realistiese minderheidsrapport ingedien en aangevoer dat verskillende tale, geskiedenisse, rasse, nasionaliteite en verskille op dogmatiese en kerkregtelike terreine 'n verskeidenheid na vore bring wat 'n „institutêre verband tussen gelowiges op aarde tot 'n onbereikbaarheid" maak. In die lig daarvan het hy die idee van 'n super-sinode bo 'n nasionale verwerp. Hy het ook gemeen dat daar nie werklik 'n praktiese behoefte aan so 'n sinode bestaan nie (Acta 1949, p. 62. Vgl. Sinode 1952 , p. 236 en 238 ).

Die idee van ' $n$ werklike ekumeniese sinode is ook deur die GKN afgewys. Op die tweede GES te Amsterdam 1949 was dit duidelik dat die patroon van die WRK wat ondertussen gestig is, ook die model vir 'n Gereformeerde Ekumeniese Sinode geword het. Net soos die WRK het die GES 'n Internasionale Geref. Sendingraad opgerig - 'n gedagte wat moeilik kerkregtelik verdedig kan word. (Sinode 1952, p. 60 v). Hoewel die GES die naam "Sinode" dra, was die GES nog nooit 'n sinode in die kerkregtelike sin van die woord nie. Tog kan dit in die teenoorgestelde as die kerklike weg agenda op die tafel van sinodes bring.

Die GES bevorder die idee dat 'n kerk 'n ,genootskap" of eenheid van gemeentes is. Dit is geen sinode nie, en tog is die GES 'n ,liggaam" waarby ,kerke" as regspersone lidmaatskap verkry. So word ook met die "kerk" as 'n abstrakte persoon gereken (en nie in die sin van die universele kerk nie) wanneer oor die verhouding tussen ,kerk" en ,staat" geteoretiseer word (vgl. Sin. 1949 p. $224-229$; Sin. 1952 t.o.v. GES).

\section{Wyer kerklike gemeenskap}

Oor die Kerkbegrip is in 1949 breed besin en die teologie van Kuyper oor die kerk as instituut en organisme, ware en valse kerk, meer en minder suiwer kerke, pluriformiteit, instituut en belydenis, taak van die instituut ens. kom in die besinning sterk na vore. Hollandse teoloë Nauta, Dijk, Hepp bepleit dat die kerk die sondige drang na deelname op politieke en sosiale terrein as verleiding moet weerstaan en dit oorlaat aan die "geInstitueerde christelike lewe".

Hierdie teologiese begrippe vind hulle neerslag in 'n nuut geformuleerde begrip oor kerklike korrespondensie (gemeenskap, ooreenstemming of eenheid) wat nou voorsiening maak vir korrespon- 
densie in ruimer sin met kerke wat in Belydenis nader maar in kerkregering verder van die Geref. Kerke staan. Korrespondensie in enger sin is egter die wyse waarop kerklike eenheid en identiteit beoefen word. Met kerke wat radikaal in leer en kcrkregering afwyk, kon geen vaste betrekking aangegaan word nie (Sinode 1952, p. $235 \mathrm{v})$.

Na 1952 erken die GKSA korrespondensie in ruimer sin met die NGKSA en die NHK van Afrika en die Church of England in SA. Die Engelse kerke soos die Anglikane, Metodiste en Presbiteriaanse Kerk wys kontak met die kerke in die GES in 1952 af. Die begrip „korrespondensie" word weereens opnuut geformuleer (Sinode 1955, p. 157 v).

Sedert die Sinode van 1955 het dit al duideliker geword dat die GES geen Sinode is nie, maar 'n Ekumeniese Beraad van Gereformeerde Kerke. Anders gesê die GES is 'n konvent, verbond van Geref. Kerke (Acta 1955, p. 307). Op sterkte van hierdie verbondenheid het die GKSA hom in 1955 radikaal teen die WRK en die Wêreld Alliansie van Presbiteriaanse Kerke uitgespreek, omdat van die basiese konsensus waarop organisatoriese eenheid moet rus, nl. die belydenis, nie erns gemaak word nie.

Kerkregtelik beskou wou die GKSA organisatoriese verbintenisse slegs met die kerkgemeenskappe aangaan met wie 'n geloofseenheid in dieselfde geloofsbelydenis erken kon word.

\section{INSTITUSIONELE ON'TWIKKELINGE BINNE DIE GKSA}

\section{Die Verkleinde Sinode}

Hoewel die Dordtse KO sedert 1863 vir die kerkorganisasie van GKSA gegeld het, is daar nie volgens die konfederatiewe patroon van die DKO van kerkraad na klassis, van klassis na partikuliere sinode en van partikuliere sinode na nasionale sinode afgevaardig nie. Elke kerkraad het regstreeks na die verskillende kerkvergaderings afgevaardig. Dit het al moeiliker geword om die lywige nasionale sinode te huisves en te hanteer. Die Sinode van 1952 met sy 220 afgevaardigdes wou die sinode verklein sonder om dic kontinuiteit (?! persone?) of die kontak met al die kerke (gemeentes) te laat verlore gaan. Die voorstel in 1955 is nog weer na 1958 oorgedra. Toe is besluit dat vyf partikuliere sinodes ' $n$ nasionale sinode sal saamstel deur elkeen 15 predikante en 15 ouderlinge te deputeer.

Die verkleining van die nasionale sinode val saam met die eeufees. In teorie plaas die verkleining die aksent vir die kerkregering sterker op die klassisse en partikuliere sinodes as samekomste van meer as een klassis. In praktyk kan die verkleinde sinode sinodokrasie bevorder. Minder predikante kan makliker ter sinode 'n bepaalde rigting bevorder terwyl die res daarbuite staan en onbetrokke bly juis omdat hulle nie na die sinode gedeputeer was nie. Daar kan maklik 'n kloof ontstaan tussen sinodale besluite en die kerklike lewe in die gemeentes. Wanneer bepaalde kerklike aktiwiteite op 'n bepaalde ,vlak" of vir 'n bepaalde ,vergadering” gereserveer word, raak dergelike aktiwiteite inderdaad 'n groot aantal kerke en kerkdienaars nie meer nie. H. J. Hegger het onlangs van 
die Sinode van die GKN gesê dat dit soos 'n satelliet gelanseer is wat ver buite die sfeer van die eintlike kerklike lewe sirkel. Die Verkleinde Sinode hanteer makliker maar verg seker veel versigtigheid en gevoeligheid ten opsigte van sy taak en werkswyse om werklik sinode te wees waar al die kerke saamkom om met mekaar in sinode besluite te neem. Die beginsel van art. $30 \mathrm{KO}$ moet gehandhaaf word om die kerklike lewe waarlik in die kerke en klassisse te laat pols.

In die latere ontwikkeling het die ideaal om ,afgevaardig" te word na sinodes by predikante 'n rol gespeel sodat klassisse gevorm is en Part. Sinodes met aantal klassisse "gebalanseer" is, sodat Klerksdorp en Tsumeb uiteindelik in een Part. Sinode saamwcrk. In hierdie opset speel institusionele dwang en geen belange van plaaslike kerke en "naburigheid" van kerke die hoofrol.

2. Rasse- en Volkereverhoudinge en die Algemene Sinode in 1966

Verskillende faktore het na die oorlog die gereformeerde sending gestimuleer, o.a. die koms van Nederlandse Gereformeerde immigrante, aandag op volkereverhoudinge a.g.v. regeringsbelcid sedert 1948, ywer van individue en deputate soos dr. J. A. Schutte en gevolglike besoeke van prof. J. H. Bavinck, ekonomiese groei en welvaart wat stoflike middele meer beskikbaar gemaak het, ens. Die belangrikste faktor was egter die toepassing van die kerkregtelike beginsel dat sending deur die plaaslike kerke en nie deur sinodale deputate onderneem, beheer en gedoen moet word nie. $\mathrm{Na} 1945$ het die gesonde verskynsel hom voorgedoen dat plaaslike kerke en selfs individue sending onderneem het - soms in samewerking met sinodale deputate soos die Sendingorde kollegialisties voorgeskryf het. Gelukkig het talle mense en kerke in eie verantwoordelikheid aan Christus, selfs teen die wense van sinodale deputate in, sending gedoen. Die Sendingorde is telkens „hersien" maar het oorbodig en in onbruik geraak. Die polsende aktiwiteite het 'n hele aantal nuwe kerke rondom die stede en selfs in verskillende volkstate tot gevolg gehad.

Nadat die begrip ,apartheid" in 1948 so aktueel in die politiek geword het, het die Sinode van 1955 besluit dat die begrip naas politieke en sosiale ook 'n kerklike dimensie het en gevolglik in die lig van die Skrif bestudeer moes word (Acta p. 143). Indringende rapporte het voor die Sinodes van 1958 en 1961 gedien waarin vasgestel is dat die Skrif geen normatiewe rasse-indeling van mense ken nie, maar dat nasionale en kulturele verskeidenheid wel erken word. Die verskeidenheid sluit egter nie die eenheid uit nie. Etniese verskeidenheid kom dus binne 'n konfessionele eenheid voor en omgekeerd kom eenheid in die verskeidenheid na vore (Hand. Sin. 1961, p. 43 v., 115 v.). Daarmee het die Sinode die beginsel van "voogskap" van volk (ras) oor volk (ras) uit die Koloniale tydperk verwerp en wegbeweeg van „rassediskriminasie" lank voordat dit in die politieke arena of by ander Afrikaanse Kerke ingang gevind het.

Die Sinode van 1961 het daarom reeds die fondament gelê vir verdere ontwikkeling. Die GKSA sou predikante vir die jong 
kerke oplei totdat hulle self in etniese verbande die taak kan oorneem. Tog was plaaslike en sinodale sending nog grootliks vermeng en verwar (Vgl. Acta 1961, p. 163-213).

Die Sinode van 1964 het in meer as een opsig die kerkregtelike fondament vir die ontwikkeling van die GKSA in die 2de eeu gelê. In ietwat nog rasseterme word 'n ,nie-blanke kerkverband" uitgestippel (Acta, p. 261 v.). Vir die verskillende samekomste van kerke word die volke of etnisiteit egter wel in ag geneem (p. 263). Daar word nie aan net een ,swart" sinode op rassegrondslag gedink nie. Die inrigting van 'n afsonderlike „Kleurling”-sinode verraai egter weer die nawerking van die rasse-indeling uit die Koloniale tydperk. Ander sinodes word weer nie volgens rasse of volke nie maar volgens gebiede (behalwe by die Kleurlinge) genoem (p. 265). Elke Sinode sal egter self sy naam vasstel (p. 266). Die cenheid in kerkregering binne 'n ,ekumeniese" sinode van die verskillende Gereformeerde nasionale sinodes „insluitende die blanke volksgroep" (p. 267), word aanvaar. Gevolglik moet die verskillende nasionale (etniese) sinodes saam in Algemene Gereformeerde Sinode oor gemeenskaplike sake besluit (p. 268 v.). Tegelykertyd gaan naas die „gemeenskaplike sinode" nog korrespondensie tussen plaaslike kerke en kerkvergaderinge onder verskillende etniese groepe, juis kragtens die ekumeniese verband tussen hulle, deur. Sodoende kan deputate oor-en-weer klassisse bywoon, adviseer ens. (p. 268 v.).

Kragtens hierdie besluit het die eerste Algemene Sinode van die Geref. Kerk in SA in 1966 te Potchefstroom saamgekom. Hierdie ontwikkeling is seker die belangrikste kerkregtelike ontwikkeling na die Oorlog vir die GKSA en vir toekomstige kerklike en politieke ontwikkeling in Suidelike Afrika. Na die Algemene Sinode te Hammanskraal in 1975 het die Nasionale Sinode van 1976 besluit dat wysiging van Belydenis en Kerkorde voortaan slegs in Algemene Sinode behartig kan word. Verskillende artikels van die Kerkorde is deur die Algemene Sinode dan ook sodanig gewysig dat dié Sinode natuurlik en organies by die kerkinrigting betrek is (Acta 1976, p. 431-437).

\section{Die ouderling as kerkregeerder}

Definisies oor presbiteriale kerkregering verskil ook in geledere binne die GKSA. Sommige sê presbiteriale kerkregering gaan van die kerkraad as kollege van ouderlinge uit. Hoewel nie altyd so gesê word nie, reken sommige by die kerkraad alle ,ampsdraers", ook die diakens. Dit is opmerklik dat toe die GKN die advies van die GKSA oor die diaken op meerdere vergadering gevra het, die Sinode van 1955 teenoor die aanbevole begrippe „smalle" en „breë" kerkraad, nie van die begrip „ampsdraer" nie, maar van „ouderling" (presbiter) uitgegaan het en aan die diaken in hierdie kerkregering slegs as "hulp" of adviseur van die ouderling 'n plek toegeken het (Acta 1952, p. 161; 1955, p. 348). Waar Calvyn en die DKO primêr van die roeping van God tot 'n bepaalde diens of funksie as instrument van Christus uitgaan, moet vasgehou word aan die feit dat Gereformeerde kerkregering basies deur die presbiter as bedicnaar van Christus uitgeoefen word en dat presbiters 
eers sekondêr in die kerkraad met die oog op hulle bediening (nl. dic tug) saamkom.

\section{SPANNING TUSSEN SENTRALISASIE EN DESENTRALISASIE}

In inleiding is opgemerk dat in die kerkregtelike ontwikkeling na die Oorlog meer as voor die Oorlog spanning tussen die tendens tot sentralisasie d.m.v. sinodes teenoor vryheid en desentralisasie in die plaaslike kerke voorkom. Die spanning tussen hierdie pole word gewoonlik as dié tussen „plaaslike kerk” en ,kerkverband" verwoord. Wanneer etikette uitgedeel word heet dit gewoonlik ,independentisme” teenoor „kollegialisme". In GKSAkringe is eersgenoemde 'n groter ,gogga" as laasgenoemde. In talle voorbeelde kom die sentraliserende neiging na 1949 na vore.

\section{Kerkraad en meerdere vergadering}

Die Sinode van 1949 verraai 'n kerkregtelike tendens tot sinodokratisering wanneer die woorde in art. $30 \mathrm{KO}$,wat by die meerdere vergadering tuishoort" verander word na "of wat die belange van al die Gemeentes van die meerdere vergadering raak" (Acta, p. 260). Die prioriteit van die „meerdere vergadering" t.o.v. die ,gemeentes" is duidelik. Klassikale optredes i.v.m. die ondertekeningsformulier (d.w.s. wat by klassisse tuishoort) word deur sinode gereglementeer (p. 326).

In 1952 word gesoek na 'n meer doeltreffende stelsel van attestasies (terwyl attes regtens by die kerkraad tuishoort) en 'n „eenvormige lidmaatregister" ontwerp (1952, p. 269). Die Sinode 1952 ontwerp skemas vir attestasies en ,bewys van lidmaatskap" (p. 291 v.). Die institusionele (genootskaplike) kerkbegrip gaan voorop, hoewel nog van „opsegging van gemeenskap met die Geref. gemeente ." gepraat word (pp. 291 v., 297).

Wanneer van die besluite o.a. oor „bewys van lidmaatskap" bevraagteken word, herroep die Sinode van 1958 alle besluite wat vorige Sinodes oor "lidmaatskap“ geneem het en verklaar dat lidmaatskap as sodanig tuishoort by die plaaslike kerk (p. 138). Moontlik het die naderende eeufeesviering die Sinode van 1958 laat terug. keer na die beginsel van art. $30 \mathrm{KO}$.

\section{Die Eeufeesbedieningsfonds}

'n Grootskaalse finansiële veldtog is van sinodeweë met 'n Eeufeesbedieningsfonds geloods. Die rente moes meerdere bediening in kerke bevorder. Daarvoor is 'n „Deputaatskap" in die lewe geroep om m.b.t. bediening "toesig te hou en te adviseer". Vir die fonds word van elke lidmaat ,'n offer van dank gebring soos maar eenmaal in 'n menseleeftyd gebring kan word", terwyl die offer wesenlik by die plaaslike kerk tuishoort (Heid. Kat. Son. 38 word hier by 'n sinodale sustentasiefonds betrek. Vgl. Acta, p. 249, 255). So beweeg die sinode in op sake wat tot die intieme wese van die plaaslike kerk behoort omdat dit pragmaties is. Aan die ander kant besluit die Sinode van 1949 dat die onderhoud van predikante by die plaaslike kerkrade gelaat en geen sinodale salariskas of salarisskaal ingestel word nie (Acta, p. 253). Sou die praktiese probleme 
wat kon opduik hier weer die beginsel van plaaslike vryheid en verantwoordelikheid beskerm het?

\section{Visitasie}

Die klassisse het gewoonlik onder art. 41 KO met 'n elftal vrae jaarliks 'n verslag van elke kerk aangehoor. In 1955 word die verwarring m.b.t. die „toesig" deur die klassis ingesien. Die vrae wat onder art. 44 i.v.m. visitasie gebruik was, het verslae onder art. $41 \mathrm{KO}$ geword. Die Sinode beklemtoon visitasie om meer vastigheid aan die gemeentes te gee, maar waarsku saam met Bouwman dat wanneer visitasie nie die lewe van elke gemeente bevorder nie, lei visitasie tot verbastering sodra daar 'n ,hierargiese suurdeeg" insluip. Dit gebeur wanneer die klassis of die visitatore met 'n beroep op die klassis die plaaslike kerke oorheers. (Acta 1955, p. 182).

'n Noukeurige studie van die visitasiepraktyke van 1955-1978 mag aan die lig bring dat visitasie inderdaad die patroon van klassikale inspeksie en selfs intervensie in baie gevalle aangeneem het en dat van tydige en gerigte hulp by die kerk ter plaatse (art. $44 \mathrm{KO}$ ) min tereg gekom het. Nie die hulp en werk van die visitatore in die betrokke Kerk nie, maar die „rapport" aan die volgende klassis het die aksent verkry. So dien visitasie die proses van sentralisasie en gepaardgaande word plaaslike aktiwiteit en verantwoordelikheid afgebreek.

\section{„Deputaatskap" vir diakensake}

Die tendens tot kerkregtelike sentralisasie kom sterk by die „Deputaatskap" vir diakensake na vore. Die „Deputaatskap” registreer as "regspersoon" en beskou hom as ,kerklike liggaam", in stryd met art. $49 \mathrm{KO}$. Omdat die vereistes van die Maatskappywet met die Kerkorde onversoenbaar is, is 'n soort middeweg by die Registrateur van Aktes gegaan (Acta, 1949, p. 162). Vir die sinodale aksie word 'n ,organiserende sekretaris en die opening van 'n kantoor" daargestel in ,belang van die diakonale stigtinge". Die sentralisasie sal $10 \%$ van die ,inkomste" van die stigtinge opneem.

Die Gereformeerde kerkreg (vgl. art. 25, 40 DKO en Bevestigingsformulier) plaas die diakonale barmhartigheid konkreet in die kerk en konkrete gemeenskap van mense onder leiding van die diakens. Barmhartigheid is primêr die roeping van elke gelowige in die plaaslike kerk. $\mathrm{Na} 1933$ word die diens geinstitusionaliscer onder 'n eie sentrale deputaatskapsbeheer (hier pas „deputaatskap" eerder as "deputate"). Die deputaatskap gee in 1949 toe dat ,diakonale en kerklike beheer mekaar oorvleuel en ingewikkeld is" (Acta p. 163). Die onderskeid tussen ,kerklike" en ,diakonale" dui skynbaar op die gesentraliseerde „deputaatskap”. Die Deputaatskap word 'n ,,sinodale liggaam" wat met die „diakonale bestuur" van inrigtinge moet saamwerk. Sommige plaaslike kerke het nog weerstand gebied teen hierdie gereglementeerde barmhartigheid. Die deputaatskap gee toe dat hulle nog 'n ,brug tussen beginsel en praktyk" soek (Acta, 1949, p. 165).

Die tendens tot sentralisasie laat die Konferensie van diakonieë 
met sy eie Uitvoerende Kommissie voor die Sinode van 1952 optree. Al die diakonieë doen nie aan die Konferensie mee nie, maar deur die Konferensies word samewerking tussen die Deputaatskap en die diakonieë van Transvaal beoefen. Die beleid word genoem „, sentralisasie van diakonale werksaamhede", sonder om daarmee die plaaslike diakonieë te wil ,,aantas" (Acta, 1952, p. 328). Aan die patroon is daar sedert 1952 meer en minder geskawe. Diakonale Konferensies is selfs alle offisiële bestaansreg ontneem-maar die sg. „deputaatskap" verteenwoordig nog steeds die gesentraliseerde patroon.

Daarnaas het ander kerkrade met Die Gereformeerde Stigting weer getrag om meer reg te laat geskied aan die beginsel dat barmhartigheid plaaslik deur die kerk moet geskied. Die spanning by die Sinodale Deputate teenoor die Gereformeerde Stigting, dui daarop dat die Deputate as 't ware op ' $n$ monopolie van ondersteuning uit die plaaslike diakonieë wil aanspraak maak en daarom moeilik bestaansreg aan ander vorme van hulpbetoon op plaaslike basis kan duld. Ondertussen het die Gereformeerde Stigting op sy beurt ook weer probeer om „sinodaal" gelegitimeerd te raak.

\section{Sinodale Sending}

Volgens Geref. Kerkreg is sending ook taak van die plaaslike kerk (Art. $7 \mathrm{DKO}$ ). Die Sendingorde wat in 1949 hersien word, maak egter onderskeid tussen 'n sendingtaak van die plaaslike gemeente en dié van meerdere vergaderinge (Acta 1949, p. 101, art. 1). Die werk van die plaaslike kerk word gereglementeer (SO art. 2-12). Daar is selfs 'n appèlreg teen 'n sendende kerkraad na ,sendingdeputate van die meerdere vergaderinge" moontlik. Gepaard hiermee word aangedring op 'n sekretaris en 'n kantoor. In 1949 wil die Sendingdeputate duidelik dieselfde kerkregtelike weg as die Deputaatskap vir diakonale sake opgaan. Die Sinodes van 1949 en 1952 wou hieraan nog nie gevolg gee nie (1952, pp. 42 en 48 ).

Hoewel die volume werk plaaslik en sinodaal geweldig uitbrei, is dit opmerklik dat die Sendingdeputate self in 1961 die aandrang op ' $n$ voltydse sekretaris met 'n sentrale kantoor temper. Dit dui daarop dat daar iets rondom die eeufeesjaar gebeur het, wat die sentralisering en sinodokratisering van werk wat tot die roeping van die plaaslike kerk behoort, gestuit het. Indien 'n mens let op die frekwensie waarop sinodes tot 1964 aandag aan 'n ,,Sendingorde" moes gee waarna selfs in die KO verwys is, het die reglement na 1964 totaal verdwyn. Dit dui op 'n gesonde ontwikkeling wat van mondigheid en weersin teen reglementering getuig.

\section{Sinodale Kategese}

Die deputate vir Katkisasie (kategese is by uitstek diens van die Woord in die plaaslike kerk) wil die kategese ook stelselmatig sentraliseer. Teen 1949 gee die deputate 'n eie blad uit wat katkisasielesse en voorligting bied. Die deputate verklaar dat hulle behoefte het aan "nuwe masjinerie" om hierdie take uit te voer. Hulle wil „katkiseermeesters” oplei en eksamineer, „Bybelkennis- 
eksamen" afneem, ens. (Acta, p. 87). Na die Sinode van 1955 het die Deputate daadwerklik ook 'n „Katkisasicorganiseerder” met 'n eie kantoor benoem. Op die Sinode van 1958 het 'n beswaarskrif hierdie handslwyse aan ' $n$ indringende toets in die lig van Gereformeerde kerkregtelike beginsels onderwerp (Acta, 1959, p. 318-357).

Die Sinodes van 1939, 1942 en 1945 het hulle teen so 'n voltydse katkisasieorganiseerder uitgespreek omdat katkisasie die opdrag aan die leraar in die plaaslike kerk is. Die ,deputaatskan" het sonder sinodeopdrag 'n predikant vir sinodale kategese aangestel en beheer. In die Gereformeerde kerkreg het deputate slegs uitvoerende gesag en kan hulle nooit namens 'n sinode regeer nie (Art. $49 \mathrm{KO}$ ). Deputate is persone wat ' $n$ opdrag of besluit van die kerke in sinode geneem uitvoer - en geen bestuursliggaam nie. Die Sinode van 1958 het die tendens tot sentralisasic gestuit en Sinodes van 1964 en 1967 het indringend prinsipieel besin en veral beklemtoon dat kategese taak van die predikant in die plaaslike kerk is. Slegs t.o.v. 'n sinodale lesrooster wat as hulpmiddel bedoel is, kan nog iets van „eenvormigheid" of sentralisasie gelees word - hoewel dit nie so bedoel word nie.

\section{Die Kerkblad}

Hierdie blad en sy voorloper „Die Maandbode” het op privaatinisiatief ontstaan as ' $n$ blad vir die gereformeerde kerklike lewe. Later is dit sinodaal oorgeneem en het selfs die status van „offisiële orgaan" van 'n gesentraliseerde (genootskap?) GKSA bereik - met 'n eie kantoor en redakteur. Die Sinode van 1976 het egter getrag om die „offisiële" karakter aan Die Kerkblad te ontneem en daaraan bloot 'n funksioncle plek in die gereformeerde kerklike lewe te gee.

\section{IDENTIFIK $A S I E$}

In die periode na die Oorlog word indringend oor die gereformeerde kerkbegrip besin. Die gebruik was om die volksmond agterna te praat asof daar een ,kerk", die Gereformeerde Kerk in SA, bestaan waarin verskillende gemeentes tot een kerk (genootskap) saamgesnoer is. Aan die ander kant is besef dat die sogenaamde GKSA in werklikheid uit plurale kerke bestaan. Die Almanak is uitgegee onder die naam "Geref. Gemeentes in SA". Teen 1949 het die gedagte begin posvat om die idee van een sentrale institusionele eenheid "kerk" te noem en die plaaslike kerk as ,gemeente" aan te dui (Acta, 1949, pp. 234, 274). Die betrokke algemene „kerk" (GKSA) identifiseer dan elke gemeente. Die tendens tot sentralisasie in kollegialistiese sin straal uit hierdie tendens. As gevolg van die ,verwarring" is die hele saak vir studie verwys.

Die rapport in Sinode 1955 het prinsipieel die plurale identifikasie begunstig, maar om praktiese, tradisionele en populêre oorweginge binne die SA konstellasie tog besluit om die kerkregtelik plurale gemeenskap van kerke tog ter wille van die volksmond tog met die enkelvoud ,kerk" aan te dui. Die gevolg van die besinning was dat voortaan meer konsekwent die woord "kerk" vir die plaaslike kerk gebruik is (Acta, 1955, p. 70 v.). Die Sinode 
van 1955 wou nog ietwat dualisties 'n plaaslike kerk aandui as „Geref. Kerk in SA, Die Gereformeerde Kerk Pretoria". Skynbaar was die bedoeling dat dieselfde kerklike ,identiteit" in elke plaaslike kerk tot openbaring kom. Kerkregtelik is die besluit van 1955 egter onduidelik. Gelukkig het die aanbeveling om „GKSA" voor die naam van die plaaslike kerk te voeg nie navolging gekry nie. Dit moet as 'n wins in die kerkbegrip beskou word dat die plaaslike kerk vandag sonder probleme ,kerk” en „Gereformeerde Kerk” genoem kan word.

Waar die kollektiewe naam „Geref. Kerk in SA" met die nasionale sinodale verband van kerke onder die Afrikaners saamgeval het, het die ontwikkeling van kerke onder die ander volke in Suidelike Afrika met wie in een algemene sinodale verband saamgeleef word opnuut die bruikbaarheid van die begrip bevraagteken. Indien die begrip "GKSA" sy oorspronklike konotasie behou as 'n soort identiteit vir die kerke in sinodale verband met sinodes te Potchefstroom, sluit dit kerke onder die ander volke in Suidelike Afrika daarvan uit, as of hulle nie Gereformeerd of in S.A. is nic. Indien die enkelvoud Geref. Kerk in SA die historiese Afrikaanse kerkgemeenskap bedoel, lyk dit asof hierdie identiteit op kerke uit ander volke afgedruk word. Dit beklemtoon die probleem wanneer 'n „genootskap" as kerk aangedui word.

Deputate van die Nasionale Sinode Potchefstroom is tans besig om die probleem onder oë te sien. Feit is egter dat elke plaaslike kerk selfstandig die liggaam van Christus openbaar binne sy eie kulturele milieu.

Opgestel vir die SA Kerkhistoriese Werkgemeenskap oor kontemporêre SA Kerkgeskiedenis, Stellenbosch 1979.

\section{VOETNOTE}

1 Ek veralgemeen op grond van indrukke verkry uit artikels in Die Kerkblad, Sinodale Handelinge, ervaring op talle kerkevergaderings, gesprekke met kollegas, ens.

2 Vgl. B. Spoelstra: Die beginsel in Art. $30 \mathrm{KO}$, in die Skriflig, Jrg. 14, Nr. 55. Sept. 1980.

3 Vgl. Afgerolde Ilandelinge Tussenkerklike Kommissie, 1955-1977. 